\title{
Characteristics of autonomic maintenance of central hemodynamics and physical working capacity in highly qualified sprint swimmers
}

\author{
Ye. L. Mykhaliuk $11, A, B, D$, M. S. Potapenko ${ }^{1, C}$, Ye. Yu. Horokhovskyi ${ }^{2, E}$, \\ L. M. Hunina ${ }^{3, F}$, R. V. Holovashchenko $0^{4, D}$
}

${ }^{1}$ Zaporizhzhia State Medical University, Ukraine, ${ }^{2}$ Zaporizhzhia National University, Ukraine, ${ }^{3}$ Educational and Scientific Olympic Institute of the National University of Physical Education and Sports of Ukraine, Kyiv, ${ }^{4}$ Educational and Scientific Institute of Special Physical and Combat Training and Rehabilitation of the National University of the State Fiscal Service of Ukraine, Irpin

A - research concept and design; B - collection and/or assembly of data; C - data analysis and interpretation; D - writing the article; $\mathrm{E}$ - critical revision of the article; $\mathrm{F}$ - final approval of the article

The aim of the study was to analyze the features of the autonomic maintenance of central hemodynamics and physical efficiency in high-class sprint swimmers in the distance from 50 to 200 meters.

Materials and methods. The study compared indicators of the heart rate variability, central hemodynamic and physical working capacity in sprint swimmers with the following qualifications: Master of Sports, Master of Sports of International Class $(n=36)$, Candidate Master of Sports and first-class sportsman $(n=50)$

Results. It has been shown that Masters of Sports and Masters of Sports of International Class in swimming are significantly older, have longer swimming experience, higher body height and weight, greater relative indices of the physical working capacity and lower heart rate in comparison with the Candidate Master of Sports and first-class sportsmen. A tendency to the prevalence of swimmers with hyperkinetic blood circulation and vagotonia has been noted.

\section{Особливості вегетативного забезпечення центральної гемодинаміки і фізичної працездатності пловців-спринтерів високої кваліфікації}

\section{Є. ^. Михалюк, М. С. Потапенко, Є. Ю. Гороховський, А. М. Гуніна, Р. В. Головащенко}

Мета роботи - проаналізувати особливості вегетативного забезпечення центральної гемодинаміки та фізичної працездатності у плавців-спринтерів високого класу на відстані від 50 до 200 метрів.

Матеріали та методи. Порівняли показники варіабельності серцевого ритму, центральної гемодинаміки і фізичної працездатності у плавців-спринтерів рівня МС-МСМК $(n=36)$ і КМС-1 розряд $(n=50)$

Результати. Показано, що плавці рівня МС-МСМК порівняно з плавцями кваліфікації КМС-1 розряд вірогідно старші, мають більший стаж занять плаванням, довжину, масу тіла, відносну величину фізичної працездатності, меншу ЧСС; у них визначена тенденція до переважання гіпокінетичного типу кровообігу, а також серед них більше спортсменів із ваготонією.

\section{Особенности вегетативного обеспечения центральной гемодинамики и физической работоспособности пловцов-спринтеров высокой квалификации}

\section{Е. ^. Михалюк, М. С. Потапенко, Е. Ю. Гороховский, ^. М. Гунина, Р. В. Головащенко}

Цель работы - анализ особенностей вегетативного обеспечения центральной гемодинамики и физической работоспособности у спортсменов-спринтеров высокого класса на дистанции от 50 до 200 метров.

Материалы и методы. Проведено сравнение показателей вариабельности сердечного ритма, центральной гемодинамики и физической работоспособности между пловцами-спринтерами уровня МС-МСМК $(n=36)$ и КМС-1 разряд $(n=50)$.

Результаты. Показано, что пловцы уровня МС-МСМК по сравнению с пловцами квалификации КМС-1 разряд достоверно старше, имеют больший стаж занятий плаванием, длину, массу тела, относительную величину физической работоспособности, меньше ЧСС; у них отмечена тенденция к превалированию гипокинетического типа кровообращения, а также среди них больше спортсменов с ваготонией.
Modern methods of the training swimmers must be inextricably linked with well-organized medical support. Unfortunately, swimmers' coaches have no motivation the thought of some authors [3] about selection for sports swimming, which is rather subjective in most cases. It can be explained by insufficient methodological works and to apply testing to date [9]. In that regard, we agree with
Key words: swimming, heart rate variability, central hemodynamics, physical working capacity, correlation data.

\section{Zaporozhye} medical journal 2020; 22 (2), 245-249

*E-mail:

evg.mikhalyuk@gmail. com

Кнючові слова: плавання, варіабельність серцевого ритму, центральна гемопрацездатність, кореляція Ааних.

Запорізький медичний журнал. 2020. T. 22, № 2(119) C. $245-249$

Ключевые слова: плавание, вариабельность серАечного ритма, центральная гемодинамика, физическая работоспособность, корреляция Аанных.

Запорожский медицинский журнал. 2020. T. 22, № 2(119). C. $245-249$ Аинаміка, фізична lack of criteria based on modern medical and biological research.

The achievement of high sports results in swimming is largely determined by the high level of the body's energy-related processes, as well as the ability to realize its aerobic and anaerobic potencies in conditions of overcoming competitive distances [12]. Taking into account the fact that one 
of the most important systems determining the functional state of the athlete is the cardiovascular system, we examined the autonomic maintenance of central hemodynamics and physical efficiency in high-class sprint swimmers.

\section{Aim}

The aim of the study was to analyze the features of the autonomic maintenance of central hemodynamics and physical efficiency in high-class sprint swimmers in the distance from 50 to 200 meters.

\section{Materials and methods}

At the beginning of the preparatory period, a comprehensive examination was conducted, which included the measurement of anthropometric indices, heart rate variability (HRV), central hemodynamics and physical working capacity in 86 swimmers (average age 16.8 \pm 0.30 years, swimming experience $-8.8 \pm 0.27$ years), specializing in the distance from 50 to 200 meters and having sport qualifications from first-class sportsman to Master of Sports of International Class (MSIC).

Mathematical methods of HRV analysis were used to analyze the autonomic regulation of cardiac activity. The following characteristics were identified: mode (Mo, s), amplitude of mode (AMo, \%), and variation range $(D, s)$. Some derived indices were calculated: autonomic equilibrium index (AMo/E, \%/s), autonomic rhythm index $\left(\mathrm{ARI}, 1 / \mathrm{s}^{2}\right)$, adequacy of regulation processes (ARP, \%/s), stress-index (relative units, r.u.). Analysis and estimation of frequency components of cardiac rhythm was carried out by examining spectral indices of autocorrelation functions: total power (TP) of spectrum $\left(\mathrm{ms}^{2}\right)$, power in the range of very low frequencies $\operatorname{VLF}\left(\mathrm{ms}^{2}\right)$, power in the range of low $L F\left(\mathrm{~ms}^{2}\right)$ and high $\mathrm{HF}\left(\mathrm{ms}^{2}\right)$ frequencies, $\mathrm{LF}$ and $\mathrm{HF}$ in normalized units (LFN and HFN, \%, relative units).

The analysis of the autonomous nervous system was carried out using a stress-index, an integral indicator of HRV. According to the recommendation of R. M. Baevskii [1], vagotonia is considered if stroke index (SI) is less than 50 r.u., eutonia - if SI is within the range of 51-199 r.u. and sympathicotonia - if SI is more than 200 r.u.

Central hemodynamics was studied by the method of automated tetrapolar rheography according to W. Kubiček et al. (1970) in Y. T. Pushkar's et al. modification (1970). Stroke volume and cardiac output (SV, CO), SI and cardiac index $(\mathrm{Cl})$, systemic vascular resistance (SVR) and systemic vascular resistance index (SVRI) were calculated.

Physical working capacity was measured according to a common technique on a cycling ergometer using a submaximal $\mathrm{PWC}_{170}$ test [13] and calculating the relative value of physical performance, i.e. $\mathrm{PWC}_{170 \mathrm{~kg}}$. The functional state index (FSI) was calculated according to the formula proposed and previously used by us.

The results of the study were analyzed statistically with Statistica for Windows 13 (StatSoft Inc., № JPZ804I382130ARCN10-J). All the data were presented as the sample mean $(M) \pm$ the standard error $(m)$. The significance of average differences was analyzed by two-tailed $\mathrm{t}$-test for independent samples. The difference between two subsets of data was considered statistically significant if a significance level $P$ (P-value) was less than 0.05. Pairwise
Pearson correlation was used to analyze the association between HRV, central hemodynamics and physical working capacity indices.

\section{Results}

The results of anthropometric indices measurements in swimmers showed that in the whole group, the body height was $-181.6 \pm 0.87 \mathrm{~cm}$, and the body weight $-70.60 \pm$ $1.01 \mathrm{~kg}$. From the time and frequency indicators of HRV, the stress index should be noted, as its average value was $54.84 \pm 5.11$ r.u., which corresponded to eitonia, and the sympathetic index was $1.703 \pm 0.139$ r.u., corresponding to its normal value.

Among the central hemodynamics indices, the mean value of $\mathrm{HR}$ was $58.520 \pm 1.067 \mathrm{bpm}, \mathrm{SI}-49.05 \pm 0.82$ $\mathrm{ml} \cdot \mathrm{m}^{-2}, \mathrm{Cl}-2.870 \pm 0.044 \mathrm{l} \cdot \mathrm{min}^{-1} \cdot \mathrm{m}^{-2}, \mathrm{SVRI}-29.44 \pm 0.52$ r.u., and the average $\mathrm{Cl}$ value corresponded to the eukinetic type of circulation. The relative value of physical working capacity was $17.17 \pm 0.31 \mathrm{kgm} \cdot \mathrm{min}^{-1} \cdot \mathrm{kg}^{-1}$, IFS $6.422 \pm 0.166$ r.u. Distribution of the swimmers by circulatory type (CT) showed that $43.0 \%, 50.0 \%$ and $7.0 \%$ of the athletes were classified as hypokinetic, eukinetic and hyperkinetic $\mathrm{CT}$, respectively. This showed a trend to eukinetic $C T(P=0.358)$ and confirmed the mean $C l$ values. The initial autonomic tone in the swimmers, according to the classification proposed by R. M. Bayevskiy [1], was as follow: $65.0 \%$ - vagotonics, $33.7 \%$ - eutonics and $1.3 \%$ sympathicotonics. This reliably indicated the prevalence of swimmers with vagotonia $(P=0.006)$ and eutonics $(P=0.023)$ compared with sympathicotonics. The FSI mean value was $6.422 \pm 0.166$ units, which rated the level "below average" according to our classification.

A correlation analysis of the studied indicators revealed a positive correlation between $\mathrm{Mo}$ and $\mathrm{SI}(\mathrm{r}=0.377$, $P=0.0001)$, Mo and SVR $(r=0.414, P=0.0001)$, Mo and SVRI $(r=0.526, P=0,0001)$, Mo and $P W C_{170 / k g}(r=0.480$, $P=0.0001)$, Mo and IFS $(r=0.307, P=0.004)$, VPR and $H R$ $(r=0.360, P=0.001)$, VPR and $\mathrm{Cl}(R=0.312, P=0.003)$, stress-index and HR $(r=0.239, P=0.026)$, stress-index and $\mathrm{Cl}(r=0.259, \mathrm{P}=0.016)$, and negative - between Mo and $\mathrm{HR}(r=-0.773, \mathrm{P}=0.0001)$, $\mathrm{Mo}$ and $\mathrm{Cl}(r=-0.466$, $P=0.0001)$, VPR and SVR $(r=-0.337, P=0.002)$, VPR and SRVI $(r=-0.349, P=0.001)$, stress-index and SVR $(r=-0.303, P=0.005)$, stress-index and SRVI $(r=-0.305$, $P=0.004)$.

Concerning the correlation of Mo, which indicates the most probable level of cardiovascular functioning, its association confirmed the fact of vagus control over the sinus node. This contributed to a decrease in $\mathrm{HR}$ and $\mathrm{Cl}$, and manifested as an economy of the circulatory system and was associated with increased physical working capacity. It is known that the autonomous rhythm index makes it possible to conclude about the autonomic balance, as the lower its value, the more the autonomic balance is shifted towards the parasympathetic regulation prevalence. In our study, the most interesting was the positive association between VPR and $\mathrm{Cl}$, indicating that the decrease in VPR was followed by a decrease in $\mathrm{Cl}$, which is energy-efficiently for the athletes' cardiovascular system.

However, the positive relationship between the stress-index and the $\mathrm{Cl}(r=0.259, \mathrm{P}=0.016)$ was the most signi- 
ficant. This indicated the direct effect of the autonomous nervous system on the integral index of central hemodynamics when the decrease in the stress-index was followed by a decrease in the $\mathrm{Cl}$, which approximated the values of the hypokinetic type of circulation. Among the remaining indicators, there were no significant correlations.

To facilitate a correct interpretation of the data obtained, all the swimmers were divided into two groups by sports qualification.

Group I ( $n=36)$ were Master of Sports (MS) and Master of Sport of International Class (MSIC) swimmers (average age $18.61 \pm 0.41$ years, experience in swimming $10.40 \pm 0.44$ years, body height $-186.60 \pm 1.23 \mathrm{~cm}$, body weight $-77.2 \pm 1.36 \mathrm{~kg})$.

Group II $(n=50)$ were Candidate Master of Sports (CMS) and first-class swimmers (average age $15.60 \pm 0.33$ years, experience in swimming $7.63 \pm 0.23$ years, body height $178.00 \pm 0.92 \mathrm{~cm}$, body weight $65.90 \pm 0.98 \mathrm{~kg}$ ).

When comparing anthropometric indices, it was found that the body height and weight of Group I swimmers were greater compared to Group II swimmers with a high degree of statistical significance $(P=0.00001)$. For most time and frequency indicators of HRV, there were no significant differences between groups. In particular, the stress-index was within the range of $51.13 \pm 6.05$ r.u. in Group I, and up to $57.51 \pm 7.66$ r.u. in Group II, which corresponded to the eutonia state. The average HR value was the lowest in Group I $-56.00 \pm 1.76$ bpm, compared to Group II $-60.40 \pm 1.35$ bpm (P=0,047). In Group I, the average $\mathrm{Cl}$ was $2.795 \pm 0.058 \mathrm{~L} \cdot \mathrm{min}^{-1} \cdot \mathrm{m}^{-2}$, in Group II $-2.925 \pm 0.063 \mathrm{~L} \cdot \mathrm{min}^{-1} \cdot \mathrm{m}^{-2}$, which were comparable and consistent with the eukinetic CT. It should be noted that the average SVR values between the studied groups were statistically insignificant, but the SVRI were greater in Group I than in Group II (30.78 \pm 0.76 r.u. versus $28.47 \pm 0.69$ r.u. $(P=0.029)$.

A ratio of CTs in swimmers with different sports classes was interesting. Thus, in the group of MS and MSIC swimmers, it was as follows: $50.0 \%$ : $44.4 \%$ : $5.6 \%$ of hypo-, eu- and hyperkinetic type, respectively. That is, there was a tendency to hypokinetic CT $(P=0.744)$ prevalence compared to eukinetic and hyperkinetic CT $(P=0.872)$. In the group of first-class and CMS swimmers, the $\mathrm{CT}$ ratio was as follows: $38.0 \%$ : $54.0 \%: 8.0 \%$ of hypo-, eu- and hyperkinetic CT, respectively. That means, there was a tendency to the eukinetic CT prevalence $(P=0.284)$. It should be noted that in the groups, with raising of the sports class, there were a tendency to increase in the number of swimmers with hypokinetic CT (from $38.0 \%$ to $50.0 \%$ ) and decrease in the number of swimmers with hyperkinetic TC (from $8.0 \%$ to $5.6 \%$ ).

In the group of MS and MSIC swimmers, the ratio of autonomic tone was $61.1 \%: 38.9 \%: 0.0 \%$, and in the group of first-class and CMS swimmers - 68.0 \%: $30.0 \%: 2.0 \%$, corresponding to vagotonia, eutonia and sympathicotonia, respectively. Thus, the lower the sports class of swimmers, the greater number of athletes with vagotonia $(P=0.092)$. It should be noted that according to the data of I. M. Kurbanova [8], in young swimmers, with raising of the sports class from the third-class sportsman to MS, the percentage of normotonics significantly decreases and the proportion of sympathicotonics is nearly tripled.
The relative value of physical working capacity was the greatest in Group I $-18.37 \pm 0.37 \mathrm{kgm} \cdot \mathrm{min}^{-1} \cdot \mathrm{kg}^{-1}$ in comparison with Group II $-16.30 \pm 0.41 \mathrm{kgm} \cdot \mathrm{min}^{-1} \cdot \mathrm{kg}^{-1}$ $(P=0.0006)$.

The FSI was significantly higher in Group I compared to Group II (6.924 \pm 0.205 versus $6.061 \pm 0.233$ r.u., $P=0.009$ ). At the same time, according to our classification, swimmers of both groups matched the level "below average" on this index.

The correlation analysis of the studied indicators in Group I swimmers showed a positive correlation between Mo and SVR ( $r=0.630, P=0.0001)$, Mo and SRVI $(r=0.615, P=0.0001)$, Mo and $P W C_{170 / k g}(r=0.442$, $P=0.007)$ and a negative correlation between Mo and $\mathrm{HR}(r=-0.752, \mathrm{P}=0.0001)$ and $\mathrm{Mo}$ and $\mathrm{Cl}(r=-0,519$, $P=0.001)$. The correlation between $\mathrm{Mo}$ and $\mathrm{PWC}_{170 / \mathrm{kg}}$, as well as $\mathrm{Mo}$ and $\mathrm{Cl}$, is very important, as it shows that the increase in the athlete's current functional state, manifested by the HR decrease, is followed by high physical working capacity and low $\mathrm{Cl}$ values which come close to hypokinetic CT.

The similar analysis of the studied indicators in firstclass and CMS swimmers showed positive correlation between Mo and $\mathrm{SI}(r=0.501, \mathrm{P}=0.0001)$, Mo and SVR $(r=0.332, P=0.018)$, Mo and SVRI $(r=0.401, P=0.004)$, Mo and $P W C_{170 \mathrm{~kg}}(r=0.427, P=0.002)$, stress-index and $\mathrm{Cl}(r=0.385, P=0.006)$ and negative correlation between Mo and $\mathrm{HR}(r=-0.770, P=0.0001)$, $\mathrm{Mo}$ and $\mathrm{Cl}(r=-0.411$, $P=0.003$ ). Swimmers of this classes as well as MS and MSIC athletes had rather strong positive correlation between $\mathrm{Mo}$ and $\mathrm{PWC}_{170 / \mathrm{kg}}$, $\mathrm{Mo}$ and $\mathrm{Cl}$, in addition, between stress-index and $\mathrm{Cl}$, which indicated that the decrease in stress-index was followed by a $\mathrm{Cl}$ decrease, which could reach the values characteristic for hypokinetic CT.

\section{Discussion}

In the available scientific literature, we have found some works related to the studies on the swimmers' HRV, central hemodynamics, and physical working capacity. Thus, according to the results of T. V. Krasnoperova [6] obtained during the examination of 22 swimmers, the average observed HR was $58.17 \pm 1.68 \mathrm{bpm}$. M. A. Kiryanova and I. N. Kalinina [7] found that the average HR among 24 sprint swimmers from first-class to MS sportsmen in the pre-competition period was $62.90 \pm 2.91 \mathrm{bpm}$. A. D. Vikulov et al. [2], in the middle of the competitive period among twenty 18-23-year-old swimmers from CMS to MSIC, obtain an average value of $\mathrm{HR}$ which accounted for $56.4 \pm 5.5 \mathrm{bpm}$. Our previous study has shown, that the average value of HR in 13 firstclass and CMS swimmers in the pre-competition period was $60.1 \pm 1.8 \mathrm{bpm}$, and $\mathrm{HR}$ in $12 \mathrm{MS}$ and MSIC swimmers was $55.1 \pm 2.5$ bpm [11]. Quite close values have been obtained in the present study: first-class and CMS swimmers $(n=50)$ had HR $60.40 \pm 1.35 \mathrm{bpm}$, while MS and MSIC swimmers ( $n=36$ ) had HR $56.0 \pm 1.76$ bpm. Thus, highly qualified swimmers were characterized by the average value of $\mathrm{HR}$ within $55.1 \pm 2.5-62.90 \pm 2.91$ bpm range. However, not all authors conducted their studies in the pre-competition period, which could have affected the study results. 
$\mathrm{Cl}$ as an integral indicator of the central hemodynamics ranges from $2.427 \pm 0.128 \mathrm{I} \cdot \mathrm{min}^{-1} \cdot \mathrm{m}^{-2}$ [6] to $3.099 \pm 0.080$ $\mathrm{I} \cdot \mathrm{min}^{-1} \cdot \mathrm{m}^{-2}$ among 47 examined CMS and MSIC sprint swimmers according to the study results of some authors. The previous studies conducted in 2004 showed that the average value of $\mathrm{Cl}$ in $14 \mathrm{CMS}$ athletes was $3.482 \pm 0.140$ I. $\mathrm{min}^{-1} \cdot \mathrm{m}^{-2}$, and this index in MS and MSIC athletes $(n=33)$ was $\mid \cdot \mathrm{min}^{-1} \cdot \mathrm{m}^{-2}[10]$. Our data [11] obtained by the swimmers examination have shown the value of $2.998 \pm 0.131 \mathrm{I} \cdot \mathrm{min}^{-1} \cdot \mathrm{m}^{-2}$ for first-class and CMS athletes, and $2.550 \pm 0.0921 \cdot \mathrm{min}^{-1} \cdot \mathrm{m}^{-2}$ for MS and MSIC athletes. According to the data obtained in this work examining the first-class and CMS swimmers, the value of $\mathrm{Cl}$ was $2.925 \pm 0.063 \mathrm{I} \cdot \mathrm{min}^{-1} \cdot \mathrm{m}^{-2}$, and the value obtained in the MS and MSIC swimmers was $2.795 \pm 0.058$ $\mathrm{I} \cdot \mathrm{min}^{-1} \cdot \mathrm{m}^{-2}$. Thus, for swimmers qualified from first-class sportsman to MSIC, the typical $\mathrm{Cl}$ values were at the level of hypo- and eukinetic.

Concerning the autonomous nervous system, the other integral indicator value - stress-index, obtained from the examination of 20 swimmers in the middle of the competitive period was $35.22 \pm 10.32$ r.u. [2], according to A. P. Isayev et al. [4], stress-index was $45.71 \pm 1.76$ r.u., and according to T. V. Krasnoperova [6], this index was $37.65 \pm 5.89$ r.u. In accordance with our previous results [10] obtained from first-class and CMS swimmers, stress-index was $58.85 \pm 10.38$ r.u., and for MS and MSIC athletes $53.18 \pm 19.01$ r.u. In this work, these data were $57.51 \pm 7.66$ r.u. and $51.13 \pm 6.05$ r.u., respectively. Thus, the average value of stress-index typically ranged from $35.22 \pm 10.32$ r.u. to $58.85 \pm 10.38$ r.u. in swimmers from the first-class to MSIC that corresponded to the vagotonia state.

The average value of relative physical working capacity in swimmers from the first-class to MS, according to D. V. Kaunina and A. D. Vikulov [5], was $20.53 \pm 4.72$ $\mathrm{kgm} \cdot \mathrm{min}^{-1} \cdot \mathrm{kg}^{-1}$, E. V. Kharlamov et al. [14] reported average values of $18.75 \pm 5.10 \mathrm{kgm} \cdot \mathrm{min}^{-1} \cdot \mathrm{kg}^{-1}$ for first-class swimmers and $20.08 \pm 2.56 \mathrm{kgm} \cdot \mathrm{min}^{-1} \cdot \mathrm{kg}^{-1}$ for MS athletes. E. L. Mikhalyuk [10] obtained the average value of $19.47 \pm 0.18 \mathrm{kgm} \cdot \mathrm{min}^{-1} \cdot \mathrm{kg}^{-1}$ in $9 \mathrm{CMS}$ swimmers and the result was $20.12 \pm 0.31 \mathrm{kgm} \cdot \mathrm{min}^{-1} \cdot \mathrm{kg}^{-1}$ in MS and MSIC swimmers $(n=9)$. Our data from 2007 showed the average value of physical working capacity in first-class and CMS swimmers at the level of $18.93 \pm 0.92 \mathrm{kgm} \cdot \mathrm{min}^{-1} \cdot \mathrm{kg}^{-1}$ and $20.29 \pm 0.70 \mathrm{kgm} \cdot \mathrm{min}^{-1} \cdot \mathrm{kg}^{-1}$ in MS and MSIC swimmers [10]. In this study, these values were $16.30 \pm 0.41 \mathrm{kgm} \cdot \mathrm{min}^{-1} \cdot \mathrm{kg}^{-1}$ and $18.37 \pm 0.37 \mathrm{kgm} \cdot \mathrm{min}^{-1} \cdot \mathrm{kg}^{-1}$, respectively. Thus, the sprint swimmers from first-class to MSIC had the average value of relative physical working capacity ranging from $16.30 \pm 0.41$ up to $20.53 \pm 4.72 \mathrm{kgm} \cdot \mathrm{min}^{-1} \cdot \mathrm{kg}^{-1}$. Based on the obtained average data of the studied indicators, it is possible to establish a model portrait corresponding to a high-class sprint swimmer.

\section{Conclusions}

1. Sprint swimmers from first-class sportsman to Master of Sports of International Class (average age $-16.8 \pm 0.3$ years, average swimming experience $-8.80 \pm 0.27$ years) have body height of $181.60 \pm 0.87 \mathrm{~cm}$, body weight of $70.60 \pm 1.01 \mathrm{~kg}, \mathrm{HR}$ of $58.52 \pm 1.09 \mathrm{bpm}, \mathrm{Cl}-2.870 \pm 0.044$ $\mathrm{I} \cdot \mathrm{min}^{-1} \cdot \mathrm{m}^{-2}$, stress-index $-54.84 \pm 5.11$ r.u., $\mathrm{PWC}_{170 \mathrm{~kg}}-$ $17.17 \pm 0.31 \mathrm{kgm} \cdot \mathrm{min}^{-1} \cdot \mathrm{kg}^{-1}$, IFS $-6.422 \pm 0.166$ r.u.
2. Sprint swimmers from Master of Sports to Master of Sports of International Class (average age $-18.61 \pm 0.41$ years, average swimming experience $-10.40 \pm 0.44$ years) have body height of $186.6 \pm 1.23 \mathrm{~cm}$, body weight of $77.2 \pm 1.36 \mathrm{~kg}, \mathrm{HR}-56.0 \pm 1.76 \mathrm{bpm}, \mathrm{Cl}-2.795 \pm 0.005$ $\mathrm{I} \cdot \mathrm{min}^{-1} \cdot \mathrm{m}^{-2}, \mathrm{PWC}_{170 \mathrm{~kg}}-18.37 \pm 0.37 \mathrm{kgm} \cdot \mathrm{min}^{-1} \cdot \mathrm{kg}^{-1}, \mathrm{IFS}-$ $6.924 \pm 0.205$ r.u.

3. Sprint swimmers from first-class to Candidate Master of Sports (average age $-15.60 \pm 0.33$ years, average swimming experience $-7.63 \pm 0.23$ years) have body height of $178.00 \pm 0.92 \mathrm{~cm}$, body weight of $65.90 \pm 0.98 \mathrm{~kg}$, $\mathrm{HR}-60.40 \pm 1.35 \mathrm{bpm}, \mathrm{Cl}-2.925 \pm 0.063 \mathrm{l} \cdot \mathrm{min}^{-1} \cdot \mathrm{m}^{-2}$, stress-index $-57.51 \pm 7.66$ r.u., $P W_{170 / k g}-16.30 \pm 0.41$ $\mathrm{kgm} \cdot \mathrm{min}^{-1} \cdot \mathrm{kg}^{-1}$, IFS $-6.061 \pm 0.233$ r.u.

4. In swimmers from first-class to Master of Sports of International Class, the positive correlations between Mo and $\mathrm{PWC}_{170 \mathrm{~kg}}$, stress-index and $\mathrm{Cl}$, and the negative correlation between $\mathrm{Mo}$ and $\mathrm{Cl}$ are the most significant.

Conflicts of interest: authors have no conflict of interest to declare. Конфмікт інтересів: віАсутній.

Надійшла Ао редакції / Received: 10.09.2019

Після Аоопрацювання / Revised: 23.09.2019

Прийнято Ао Аруку / Accepted: 01.10.2019

Information about authors:

Mykhaliuk Ye. L., MD, PhD, DSc, Professor, Head of the Department of Physical Rehabilitation, Sports Medicine, Physical Education and Health, Zaporizhzhia State Medical University, Ukraine.

ORCID ID: 0000-0003-3607-7619

Potapenko M. S., MD, PhD, Assistant of the Department of Anesthesiology and Intensive Care, Zaporizhzhia State Medical University, Ukraine.

Horokhovskyi Ye. Yu., PhD, Associate Professor of the Department of General and Applied Ecology and Zoology, Zaporizhzhia National University, Ukraine.

Hunina L. M., PhD, DSc, Professor, Deputy Director of the Educational and Scientific Olympic Institute of the National University of Physical Education and Sports of Ukraine, Kyiv. Holovashchenko R. V., PhD, Associate Professor of the Department of Physical Education, Sport and Human Health; Educational-Scientific Institute of Special Physical, Combat Training and Rehabilitation of the National University of the State Fiscal Service of Ukraine, Irpin.

\section{Відомості про авторів:}

Михалюк Є. А., А-р меА. наук, професор, зав. каф. фізичної реабімітації, спортивної медицини, фізичного виховання і зАоров'я, Запорізький Аержавний медичний університет, Україна. Потапенко М. С., канА. меА. наук, асистент каф. анестезіології та інтенсивної терапії, Запорізький Аержавний медичний університет, Україна.

Гороховський Є. Ю., канд. біол. наук, Аоцент каф. загальної та прикладної екології і зоології, Запорізькій національний університет, Україна.

Гуніна ^. М., А-р біол. наук, професор, заступник директора Навчально-наукового олімпійського інституту, Національний університет фізичного виховання і спорту України, м. Київ. Головащенко Р. В., канА. наук з фіз. виховання і спорту, Аоцент каф. фізичного виховання, спорту та зАоров'я Аюдини Навчально-наукового інституту спеціальної фізичної, бойової підготовки та реабілітації, Університет Аержавної фіскальної служби України, м. Ірпінь.

\section{Сведения об авторах:}

Михалюк Е. ^., А-р меА. наук, профессор, зав. каф. физической реабилитации, спортивной меАицины, физического воспитания 
и зАоровья, Запорожский государственный медицинский университет, Украина.

Потапенко М. С., канА. меА. наук, ассистент

каф. анестезиологии и интенсивной терапии, Запорожский государственный медицинский университет, Украина. Гороховский Е. Ю., канА. биол. наук, Аоцент каф. общей и приклаАной экологии и зоологии, Запорожский национальный университет, Украина.

Гунина ^. М., А-р биол. наук, профессор, заместитель Аиректора Учебно-научного олимпийского института, Национальный университет физического воспитания и спорта Украины, г. Киев.

Головащенко Р. В., канА. наук по физ. воспитанию и спорту, Аоцент каф. физического воспитания, спорта и здоровья человека Учебно-научного института специальной физической, боевой подготовки и реабилитации, Национальный университет государственной фискальной службы Украины, г. Ирпень.

\section{References}

[1] Baevskii, R. M., \& Berseneva, A. P. (1997). Otsenka adaptatsionnykh vozmozhnostei organizma i risk razvitiya zabolevanii [Assessment of the body's adaptive capabilities of and the risk of developing diseases]. Meditsina. [in Russian].

[2] Vikulov, A. D., Bocharov, M. V., Kaunina, D. V., \& Boikov, V. L. (2017) Regulyatsiya serdechnoi deyatel'nosti u sportsmenov vysokoi kvalifikatsii [Regulation of cardiac activity in athletes of high qualification]. Vestnik sportivnoi nauki, (2), 31-36. [in Russian].

[3] Gogotova, V. L., Korneyeva, I. T., \& Polyakov, S. D. (2009). Mediko-biologicheskie osnovy otbora v sportivnoe plavanie (literaturnyi obzor) [Mediobiologic base for competitive swimming evaluation (literary review)]. Lechebnaya fizkul'tura i sportivnaya meditsina, (10), 25-36. [in Russian].

[4] Isaev, A. P., Potapova, T. V., \& Erlikh, V. V. (2009). Izmenenie kardioritma i spektral'nykh kharakteristik krovoobrashcheniya yunykh plovtsov-sprinterov i staierov [The changes of cardiorhythm and spectral descriptions of the blood circulation of young spriter- and stayer-swimmers]. Vestnik Yuzhno-Ural'skogo gosudarstvennogo universiteta. Seriya: obrazovanie, zdravookhranenie, fizicheskaya kul'tura, (20), 31-36. [in Russian].

[5] Kaunina, D. V., \& Vikulov, A. D. (2012). Fizicheskaya rabotosposobnost' i lipidnyi obmen sportsmenov-plovtsov vysokoi kvalifikatsii [The Physical Working Capacity and Blood Lipids Composition of Highly Qualified Swimmers' Blood Plasma]. Yaroslavskii pedagogicheskii vestnik, 3(4), 141-144. [in Russian]

[6] Krasnoperova, T. V. (2005). Variabel'nost' serdechnogo ritma i tsentral'naya gemodinamika u vysokokvalifitsirovannykh sportsmenov s raznoi aktivnost'yu vegetativnoi regulyatsii. (Avtoref. dis...kand. biol. nauk). [Heart rate variability and central hemodynamics in highly-qualified athletes with different autonomic regulation activity]. (Extended abstract of candidate's thesis). Kirov. [in Russian].

[7] Kiryanova, M. A., \& Kalinina, I. N. (2011). Osobennosti tsentral'noi gemodinamiki u sportsmenov-plovtsov s uchetom kharaktera myshechnoi deyatel'nosti [Features of central hemodynamics in athelets-swimmers with account the nature of muscular activity]. Lechebnaya fizkul'tura $i$ sportivnaya meditsina, (6), 15-21. [in Russian].

[8] Kurbanova, I. M. (2002). Funktsional'noe sostoyanie vegetativno nervnoi i serdechno-sosudistoi sistem u yunykh sportsmenov. (Avtoref. dis...kand. med. nauk). [Functional state of autonomic nervous and cardiovascular systems in young athletes]. (Extended abstract of candidate's thesis). Ivanovo. [in Russian].

[9] Lomazova, E. V., Kalinin, A. V., Yakushev, M. P., Danilova-Perlei, V. I., \& Lobanov, M. Yu. (2013). Mesto obshchei i spetsial'noi rabotosposobnosti v sisteme podgotovki plovtsov [General and specific work capacity in the training system of swimmers]. Metody otsenki i povysheniya rabotosposobnosti $u$ sportsmenov. Proceedings of the All-Russian Scientific and practical conference with international participation (pp. 45-46). St. Petersburg. [in Russian].

[10] Mikhalyuk, E. L. (2004). Polovoi dimorfizm sredi pokazatelei tsentral'noi gemodinamiki i fizicheskoi rabotosposobnosti plovtsov vysokogo klassa [Sexual dimorphism among the indices of central hemodynamics and physical working capacity in high class swimmers]. Aktualni pytannia farmatsevtychnoi ta medychnoi nauky ta praktyky. Zbirnik naukovikh statey, (13) 142-149. [in Russian].

[11] Mikhalyuk, E. L. (2007) Diahnostyka hranychnykh ta patolohichnykh staniv pry krainikh fizychnykh navantazhenniakh v olimpiiskomu ta profesionalnomu sporti. (Avtoref. dis... dokt. med. nauk) [Diagnostics of the boundary and pathological conditions on the terminal physical exertion in the Olympic and professional sport. Dr. med. sci. diss.] Dnipropetrovsk. [in Ukrainian]
[12] Platonov, V. N. (2004). Sistema podgotovki sportsmenov v olimpiiskom sporte. Obshchaya teoriya i ee prakticheskie prilozheniya [The vocational training system of athletes in Olympic sports. General theory and its practical applications]. Olimpiiskaya literatura. [in Russian].

[13] Karpman, V. L., Belotserkovskii, Z. B., \& Gudkov, I. A. (1988). Testirovanie $v$ sportivnoi meditsine [Testing in sports medicine]. Fizkul'tura i sport. [in Russian].

[14] Kharlamov, E. V., Popova, N. M., \& Zhuchkova, I. N. (2016). Funktsional'nye pokazateli, kharakterizuyushchie vynoslivost' plovtsov i grebtsov [Functional indicators characterizing the endurance of swimmers and rowers]. Nauchno-metodicheskii elektronnyi zhurnal «Kontsept», 2, 581-585. http://e-koncept.ru/2016/46135.htm [in Russian] 